\title{
Methods of Estimating Particulates Emission in Agriculture Exemplified by Animal Husbandry
}

\author{
Michał ROMAN ${ }^{1}$, Kamil Krzysztof ROMAN ${ }^{2}$ Monika ROMAN ${ }^{1}$ \\ ${ }^{1}$ Warsaw University of Life Sciences, Warsaw, Poland \\ \{michal_roman, monika_roman\} esggw.pl \\ ${ }^{2}$ Institute of Technology and Life Sciences, Warsaw, Poland \\ k.romaneitp.edu.pl
}

\begin{abstract}
The indicators of emission from fuel combustion processes may be referred to the unit of raw material or energy obtained from combustion. They may concern a particular technology and make it possible to estimate the amount of pollution emitted to air on the basis of raw material balancing. The indicators may concern a particular technology but their basic function is to create tools that make it possible to compare the volume of pollutant emission to air per a unit of product obtained with the use of different production technologies. The article presents an analysis of the volume of pollution with PM2.5 in animal husbandry conducted in the period 2014-2016. Data concerning particular sources of emission come from the information provided by the Central Statistical Office in Warsaw. The estimation of PM2.5 and PM10 emission was conducted on the basis of the structure of sources of emission resulting from agriculture in accordance with the Tier 2 method. The analysis shows that the highest PM2.5 pollution results from pig and poultry farming and its volume accounted for 0.10 Gg in 2016.
\end{abstract}

Keywords: Particulates, PM2.5 Emission, PM10 Emission, Animal Production, Agriculture, Poland.

\section{$1 \quad$ Introduction}

Pollution with particulates is one of the most disadvantageous forms of air pollution. Particulates should be understood as "a group of solid particles that were thrown into the atmosphere and remain in it for a certain period" [11]. At present, there is a classification of particulates based on the size of particles and their impact on human health. The term total suspended particulates (TSP) means the total content of particulates in air. Particulate matter (PM10) means suspended particulates with a diameter below $10 \mu \mathrm{m}$. Fine particulate matter PM2.5 means a group of suspended particulates with a colloidal dispersion of particles with a diameter below $2.5 \mu \mathrm{m} \mathrm{[3].}$

The source of particulates is common and concerns industry as well as agriculture. For the control of the quality of air, the following classification of suspended particulate matter is used: particles with a diameter of 2,5 $\mathrm{m}$ (PM 2,5) and $10 \mathrm{~m}$ (PM 10) [20]. Fine particles hover in the air. They reach the atmosphere as a result of natural as well as anthropogenic processes [15]. The natural sources of particulates emission include deposition materials, volcano eruptions and forest fires. The artificial sources of air 
pollutants include actually all production processes and combustion (especially fossil fuel combustion) [7]. Five main categories of particulates emission sources may be distinguished: power plants, industrial energy generation, industrial technologies, other stationary sources such as boiler-plants and household fireplaces, and mobile sources [11].

In practice, the measurement is made with the use of different specialist devices depending on the size of particles. Systematic measurement of the level of air pollution with particulates in Poland is conducted in accordance with Directive 2008/50/EC and Regulation of the Minister of the Environment [5, 17]. The measurement of the suspended particulate matter (PM10 and PM2.5) is conducted by the Chief Inspectorate of Environmental Protection [8] with the use of the gravimetric method, which is recognised and used as the most precise one, as well as the automatic method [8]).

Particulates practically originate from any activity, including agricultural operations, soil cultivation, mineral fertilisation, hay collection as well as animal husbandry (fodder provision), drying, reloading, blending dry substances, grist milling, grinding, and bedding animal sheds and fodder houses [4]. Pollution with particulates in farm facilities for livestock is presented in Figure 1.

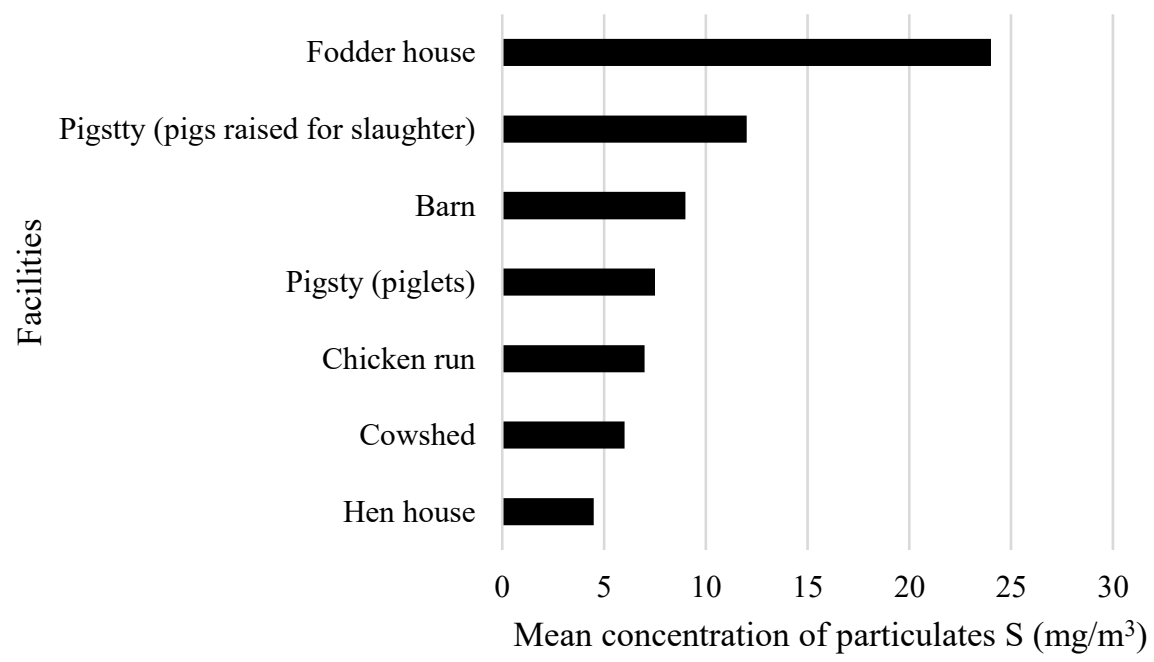

Fig. 1. Pollution with particulates in farm facilities for livestock [12].

Particulates found in agriculture are organic fine particles (of animal, plant and microorganism origin) or non-organic particles (chemicals or minerals) [18]. Agricultural particulates may contain bacteria (e.g. mites), the Acaridae (arachnids), mould, pollen, and particles of hair, feathers, skin or fur [4]. Although the structure of particulates and their fractions has an enormous impact on their movement, the spatial and climate conditions play an important role. Pollution with particulates differs depending on the place. The highest concentration of particulates is recorded in poorly ventilated closed areas (e.g. fodder houses) and places where intensive operations are 
performed, e.g. reloading or harvesting (mowing). The main climatic factors affecting the movement of fine particles in air include a strong wind and low humidity.

\section{Methodology}

The measurement of the intensity of pollution with particulates is conducted based on the factor determining air pollution. The factor of emission (EFpollutant) of PM10 and PM2.5 may be determined in different ways:

- Direct measurement conducted with the use of initial separators. Sampling consists in the division of an air stream from the source of pollution into different components based on aerodynamic features of the particulate matter. The measurement provides immediate results and makes comparison possible.

- Measurement of the share of PM10 and PM2.5 in the total particulates emission.

- Analysis of the calculation of PM10 and PM2.5 fractions in relation to TSP.

The indicators of pollutant emission are calculated in order to determine the size of emission to the atmosphere as a result of technological processes. Pollutant emission indicators are determined for most of the typical production processes in different industries. They specify typical amounts of pollutants with the greatest impact on the environment. They are emitted as a result of a certain process and expressed in units of a given pollutant mass per a unit of time, product or useful effect, and a unit of combusted fuel or energy used [14]. Emission indicators in relation to the unit of product are compared with emission standards: BAT - Best Available Technique [2].

The description of emission indicators can be found in EMEP/EEA Air Pollutant Emission Inventory Guidebook 2016 published by the European Environmental Agency. The Guidebook is aimed at serving the unification of emission inventory systems worldwide. Emission indicators are broadly developed individually for each source of emission subdivided into the following main categories:

- Combustion processes in the production of electricity and heat,

- Combustion processes in industry,

- Fuel combustion processes in heating plants and boiler-houses (other non-stationary combustion sources),

- Industrial processes (industrial technologies), including other processes except fuel combustion,

- Road transport and other transport (mobile sources), including rail transport, inland navigation, agricultural transport as well as air and sea transport,

- Waste management and treatment,

- Agriculture.

The methodology adopted in the Guidebook envisages estimation of emission at three tiers. The first basic one (Tier 1) encourages applying emission factors that represent 'typical' or 'averaged' process conditions, which are technology independent. At the second, intermediate tier (Tier 2), emission factors refer to particular technologies. On 
the other hand, the third tier (Tier 3) requires detailed data concerning facilities being the source of emission.

Below, there is a presentation of pollutants in agriculture for which emission factors are determined and the place in the EMEP/EEA Guidebook [16], where the information concerning the value can be found. It was decided to limit the list to presumed factors (Tier 1) because in most cases, the factors refer to the same substances regardless of technology used. The list of emission factors of the EMEP/EEA Guidebook [16] for agriculture is presented in Table 1.

Table 1. List of factors for agriculture [16]

\begin{tabular}{|c|c|c|}
\hline Process & $\begin{array}{l}\text { Pollutants for which emission factors are } \\
\text { determined }\end{array}$ & $\begin{array}{l}\text { Source of information } \\
\text { according to } \\
\text { EMEP/EEA }\end{array}$ \\
\hline $\begin{array}{l}\text { Manure } \\
\text { management }\end{array}$ & NH3, NO, NMLZO, TSP, PM10, PM2.5 & $\begin{array}{l}\text { Sub-chapter 3.B } \\
\text { Tables from 3-1 to 3-4 }\end{array}$ \\
\hline $\begin{array}{l}\text { Crop } \\
\text { production }\end{array}$ & NMLZO, NH3, PM10, PM2.5, NO & Sub-chapter 3.D \\
\hline $\begin{array}{l}\text { Burning of } \\
\text { stubble }\end{array}$ & $\begin{array}{l}\text { NOx, CO, NMLZO, NH3, TSP, PM10, } \\
\text { PM2.5, soot, Cd, Hg, As, Cr, Cu, Ni, Se, Zn, } \\
\text { PCDD/F, benzo(a)pyrene, } \\
\text { benzo(b)fluoranthene, benzo(k)fluoranthene, } \\
\text { indeno (1,2,3-cd) pyrene }\end{array}$ & Sub-chapter 3.F \\
\hline
\end{tabular}

The latest indicators of the emission of $\mathrm{CO}_{2}, \mathrm{SO}_{2}, \mathrm{NO}_{\mathrm{x}}, \mathrm{CO}$ and TSP in the course of electricity production were published in February 2017. In the document, there are calculated pollutant factors based on the data provided in the 2015 report by the National Centre for Emissions Management (KOBIZE). In the course of estimating the value of emission factors, fuels (including renewable ones) used in internal combustion facilities within the SNAP-0101 category (power plants and heat generating plants) and SNAP-0301 (energy industry), were taken into account. It was determined that the value of TSP emission indicator for electricity produced in combustion facilities accounts for $0.063 \mathrm{~kg} \cdot \mathrm{MWh}^{-1}$, and the value for end users of electricity is 0.062 $\mathrm{kg} \cdot \mathrm{MWh}^{-1}[10]$.

The National Centre for Emissions Management is an institution reporting the level of pollution emitted to the atmosphere. The level of particulate emission is estimated each year and published in the report entitled "Krajowy Bilans Emisji $\mathrm{SO}_{2}, \mathrm{NO}_{\mathrm{x}}, \mathrm{CO}$, $\mathrm{NH}_{3}$, NMLZO, Pyłów, Metali Ciężkich i TZO w układzie klasyfikacji SNAP i NFR". The air pollution level is calculated based on the structure of emission sources laid down in the "EEA/EMEP Emission Inventory Guidebook" [6] in accordance with the SNAP classification. The share of PM2.5 in successive years accounted for 7.25, 6.22, 1.51 and $9.68 \%$ respectively. The PM2.5 emission from selected sources in the period 2012-2015 is presented in Table 2. 
Table 2. Emission of PM2.5 in the period 2012-2015 [9, 10].

\begin{tabular}{|c|c|c|c|c|}
\hline \multirow[t]{2}{*}{ Emission source } & \multicolumn{2}{|c|}{ PM2.5 emission $[\mathrm{Mg}]$} & \multirow[b]{2}{*}{2014} & \multirow[b]{2}{*}{2015} \\
\hline & 2012 & 2013 & & \\
\hline Total & 144,771 & 144,510 & 125,520 & $124,562.5$ \\
\hline $\begin{array}{l}\text { Combustion in electricity and heat } \\
\text { production sector }\end{array}$ & 14,901 & 14,932 & 13,404 & 13,411 \\
\hline $\begin{array}{l}\text { Non-industrial combustion } \\
\text { processes }\end{array}$ & 71,679 & 73,498 & 67,102 & 66,030 \\
\hline \multirow[t]{2}{*}{ Agriculture } & 512 & 339 & 486 & 549 \\
\hline & $0.35 \%$ & $0.02 \%$ & $0.39 \%$ & $0.44 \%$ \\
\hline
\end{tabular}

The level of the PM2.5 emission in the period 2012-2015 from agriculture was presented in the table above. According to the stated hypothesis the calculation of Tier 2 method that uses the factors for particular categories of animals should compare to the National Centre for Emissions Management [10] PM2.5 emission values. The idea of confirming the hypothesis is to compare the obtained results from both sources.

\section{$3 \quad$ Research Findings}

The highest PM2.5 emission accounts for $0.129 \mathrm{Gg}$ and originates from burning agricultural residue, including grass burning, and the lowest emission accounts for $0.002 \mathrm{Gg}$ and originates from horse breeding. The level of PM2.5 emission from animal farming in 2014 according to KOBIZE is presented in Table 3.

Table 3. PM2.5 emission to air from agriculture and fuel combustion in agriculture, forestry and fishing in 2014 [13].

\begin{tabular}{llll}
\hline \multicolumn{2}{l}{ Husbandry/farming } & PM 2.5 & \\
Industry & Type & Gg & $\%$ \\
\hline Agriculture & Dairy cattle & 0.022 & 0.005 \\
& Non-dairy cattle & 0.031 & 0.006 \\
& Swine & 0.074 & 0.015 \\
& Horses & 0.002 & 0,000 \\
& Laying hens & 0.035 & 0.007 \\
& Broilers & 0.073 & 0.015 \\
& Other poultry & 0.094 & 0.019 \\
& Field burning of agricultural residues (and & 0.129 & 0.027 \\
& grass burning) & & \\
& Stationary combustion & 8.541 & 1.757 \\
& Vehicles and machinery (off road) & 8.283 & 1.704 \\
& Fishing (off road) & 0.408 & 0.084 \\
\hline
\end{tabular}


In case of animal production, emission of particulates takes place mainly during cleaning and ventilation of farming facilities, and the removal of manure and other postproduction residues. The selection of a proper method of estimating the emission of particulates from animal production, like in case of agricultural production and agricultural soil, should be done in accordance with recommendations laid down in the EMEP/EEA Guidebook [6].

In order to determine particulate emission with the use of the Tier 1 method, it is necessary to determine the right category of farm animals, including the category of cattle and swine and select a proper factor of the level of pollution. Emission of pollutants ( $\left.E_{\text {pollutant_animal }}\right)$ for the selected category of farm animals takes into account the average annual animal population $\left(\mathrm{AAP}_{\text {animal }}\right)$ and the rightly selected $\mathrm{EF}$ factor $\left(\mathrm{EF}_{\text {pollutantanimal }}\right)$. It is calculated following equation (1).

where:

$$
\text { Epollutant_animal }=\mathrm{AAP} \text { animal } \times \mathrm{EF}_{\text {pollutant_animal }}
$$

Epollutant animal - pollutant emission for the category of farm animals, $\mathrm{kg} / \mathrm{year}$,

$\mathrm{AAP}_{\text {animal }}$ - average annual animal population, head/year,

$\mathrm{EF}_{\text {pollutant_animal }}$ - pollutant factor EF.

The presumed values of the EF factor for particular categories of animals (NFR classification) are presented in Table 4.

Table 4. Presumed EF values in animal classification [1, 21].

\begin{tabular}{|c|c|c|c|c|}
\hline NFR & Animal classification & $\begin{array}{l}\text { EF for TSP }(\mathrm{kg} \\
\left.\mathrm{AAP}^{-1} \text { year }^{-1}\right)\end{array}$ & $\begin{array}{l}\text { EF for PM10 } \\
\left(\mathrm{kg} \mathrm{AAP}^{-1}\right. \\
\left.\text { year }^{-1}\right)\end{array}$ & $\begin{array}{l}\text { EF for } \\
\text { PM2.5 }(\mathrm{kg} \\
\text { AAP }^{-1} \text { year- } \\
\text { 1) }\end{array}$ \\
\hline 3B1a & Dairy cattle & 138 & 0.63 & 0.41 \\
\hline $3 \mathrm{~B} 1 \mathrm{~b}$ & $\begin{array}{l}\text { Cattle (young cattle, beef cattle, } \\
\text { and sucking cows) }\end{array}$ & 0.59 & 0.27 & 0.18 \\
\hline $3 \mathrm{~B} 1 \mathrm{~b}$ & Cattle (calves) & 0.34 & 0.16 & 0.10 \\
\hline 3B2 & Sheep & 0.14 & 0.06 & 0.02 \\
\hline 3B3 & Swine (fattening pigs) & 1.05 & 0.14 & 0.006 \\
\hline 3B3 & Swine & 0.27 & 0.05 & 0.002 \\
\hline 3B3 & Swine (sows) & 0.62 & 0.17 & 0.01 \\
\hline 3B4a & Buffalo & 1.45 & 0.67 & 0.44 \\
\hline 3B4d & Goats & 0.14 & 0.06 & 0.02 \\
\hline $3 \mathrm{~B} 4 \mathrm{e}$ & Horses & 0.48 & 0.22 & 0.14 \\
\hline 3B4f & Mules and asses & 0.34 & 0.16 & 0.10 \\
\hline 3B4gi & Laying hens & 0.19 & 0.04 & 0.003 \\
\hline 3B4gii & Broilers & 0.04 & 0.02 & 0.002 \\
\hline 3B4giii & Turkeys & 0.11 & 0.11 & 0.02 \\
\hline 3B4giv & Poultry (ducks) & 0.14 & 0.14 & 0.02 \\
\hline 3B4giv & Poultry (geese) & 0.24 & 0.24 & 0.03 \\
\hline $3 \mathrm{~B} 4 \mathrm{~h}$ & Other animals (fur animals) & 0.018 & 0.008 & 0.004 \\
\hline
\end{tabular}


The values ( $\left.\mathrm{AAP}_{\text {animal }}\right)$ should be averaged and refer to an annual scale. Livestock can be determined based on the statistical data of the Central Statistical Office in Warsaw. The emission of particulates in horse breeding and cattle farming is presented in Table 5.

Table 5. Measured PM2.5 emission [1].

\begin{tabular}{lllll}
\hline NFR & Livestock & State of matter & Emission & \\
& & & & $\mathrm{mg}$ \\
& & & $\mathrm{mg} / \mathrm{h}$ \\
\hline 3B1a & Cattle & liquid & 172.5 & 28.5 \\
& & solid & 89.3 & 28.0 \\
3B1a & Cattle (including young cattle) & liquid & 113.0 & 13.7 \\
& and dairy cattle & solid & 85.5 & 16.0 \\
3B1a & Cattle (calves) & liquid & 127.5 & 19.5 \\
& & solid & 132.0 & 27.3 \\
3B4e & Horses & solid & 448.5 & 47.5 \\
& & solid (a) & 55.0 & - \\
\hline
\end{tabular}

(a) Takai et al. 1998, Seedorf and Hartung 2001 [21, 19]

The EF measurement factors in the Tier 2 method used to determine the level of particulates in animal husbandry venues are developed individually in relation to the level of particulate emission in the given area. The research into the level of particulate emission was conducted in the period 2014-2016 and it confirmed the differences in particulate emission depending on the place of measurement. Data taken into account during the analysis are presented in Table 6.

Table 6. Data ta ken into account during the analysis.

\begin{tabular}{|c|c|c|c|c|c|c|c|c|}
\hline \multirow{2}{*}{ NFR } & \multirow{2}{*}{ Livestock } & \multicolumn{3}{|c|}{ Livestock population [mln] } & $\begin{array}{l}\text { EF } \\
\text { PM2.5 }\end{array}$ & \multicolumn{2}{|c|}{$\mathrm{AAP}_{\text {animal }}$, head/year } & \multirow[b]{2}{*}{2016} \\
\hline & & 2014 & 2015 & 2016 & $\mathrm{~kg} /$ year & 2014 & 2015 & \\
\hline 3B1a & Dairy cattle & 2,25 & 2,13 & 2,13 & 0.41 & $2,247,800$ & $2,134,091$ & $2,129,855$ \\
\hline $3 \mathrm{~B} 1 \mathrm{~b}$ & Calves & 2,89 & 3,15 & 3,36 & 0.1 & $2,894,868$ & $3,148,445$ & $3,355,103$ \\
\hline $3 \mathrm{~B} 2$ & Sheep & 0,02 & 0,22 & 0,24 & 0.02 & 201,270 & 221,187 & 244,171 \\
\hline $3 \mathrm{~B} 4 \mathrm{~d}$ & Goats & 0,08 & 0,08 & 0,04 & 0.02 & 81,727 & 81,727 & 44,204 \\
\hline 3B4e & Horses & 0,21 & 0,21 & 0,19 & 0.14 & 207,065 & 207,065 & 185,494 \\
\hline 3B3 & Swine & 11,72 & 11,64 & 1110,75 & 0.002 & $5,781,699$ & $5,740,274$ & $5,477,671$ \\
\hline 3B4gi & Hens & 41,77 & 45,63 & 47,07 & 0.003 & $6,866,134$ & $7,500,726$ & $7,737,938$ \\
\hline 3B4gii & Chickens & 88,09 & 100,49 & 121,96 & 0.002 & $14,480,822$ & $16,519,454$ & $20,048,292$ \\
\hline 3B4giv & Other poultry & 16,91 & 17,30 & 18,74 & 0.02 & $2,779,666$ & $2,844,292$ & $3,080,841$ \\
\hline
\end{tabular}

The results of the analyses of PM 2.5 levels in animal production conducted in the period 2014-2016 in comparison with the available KOBIZE analyses are presented in Table 7. 
Table 7. Results of the analyses of PM2.5 levels in animal production conducted in the period 2014-2016.

\begin{tabular}{lllllll}
\hline & & \multicolumn{2}{l}{ Epolutant_animal, Gg } & \multicolumn{2}{l}{ Epolutant_animal $^{(\text {a) }}, \mathrm{Gg}$} \\
NFR & Livestock & 2014 & 2015 & 2016 & 2014 & 2015 \\
\hline 3B1a & Dairy cattle & 0.01 & 0.02 & 0.02 & 0.02 & 0.02 \\
3B1b & Calves & 0.01 & 0.03 & 0.03 & 0.03 & 0.03 \\
3B2 & Sheep & 0.00 & 0.00 & 0.00 & & \\
3B4d & Goats & 0.00 & 0.00 & 0.00 & & \\
3B4e & Horses & 0.00 & 0.00 & 0.00 & 0.00 & 0.00 \\
3B3 & Swine & 0.02 & 0.10 & 0.10 & 0.10 & 0.10 \\
3B4gi & Hens & 0.02 & 0.03 & 0.04 & 0.03 & 0.04 \\
3B4gii & Chickens & 0.04 & 0.07 & 0.08 & 0.07 & 0.08 \\
3B4giv & Other poultry & 0.01 & 0.09 & 0.10 & 0.09 & 0.10 \\
\hline
\end{tabular}

(a)KOBIZE 2015, KOBIZE 2017 [9, 10]

\section{Conclusions}

The biggest amounts of particulates reach air from industry: energy sector, chemical industry, mining, metallurgy and construction. Removing particulates from gas is a necessity in many processes in heavy industry (e.g. ferrous and nonferrous metal making, metalworking, woodworking, plastic working), municipalities (fossil fuel combustion, and ventilation and air conditioning systems) [14] and agriculture (e.g. animal production and straw burning).

The main contribution in article is the comparison of own calculated PM2.5 levels that uses the factors for particular categories of animals to National Centre for Emissions Management PM2.5 emission analysis. The results of the analyses of the PM2.5 level in animal production conducted in the period 2014-2016 in comparison with the available analyses of the National Centre for Emissions Management [10] do not show significant differences. This statement fully confirms stated hypothesis about comparison of obtained results from both sources. The results of the analyses of PM2.5 levels in animal production were additionally calculated for the year 2016. According to estimates, the level of PM2.5 pollution in the year 2016 compared to previous years slightly increased. The increase was specially notice for hens, chickens and other poultry, by value $0.1 \mathrm{Gg}$ per year.

It was not possible to compare the level of PM2.5 for sheep and goats during the analyses. The highest pollution level was typical of swine and poultry farming for which the pollution values accounted for $0.10 \mathrm{Gg}$ according to many authors as well as the 2016 KOBIZE data [10].

\section{References}

1. Amon, B., Hutchings, N., Dämmgen, U., Webb, J.: EEA Guidebook 2016. 3B Manure Management. 1-62 (2016). 
2. Bagieński, Z.: Systemy ochrony powietrza. Wydawnictwo Fundacji na Rzecz Rozwoju Politechniki Poznańskiej, Poznań (2003).

3. Chaloulakou, A., Kassomenos, P., Spyrellis, N., Demokritou, P., Koutrakis, P.: Measurements of PM10 and PM2.5 particle concentrations in Athens, Greece, Atmospheric Environment (37). 649-660 (2003).

4. Dutkiewicz, J.: Pył występujący w rolnictwie jest niebezpieczny, Kasa Rolniczego Ubezpieczenia Społecznego. Warszawa. 1-16 (2006).

5. Directive 2008/50/EC of the European parliament and of the Council of 21 May 2008 on ambient air quality and cleaner air for Europe. OJ L 152 of 11.06.2008. 1.

6. EMEP/EEA. Air Pollutant Emission Inventory Guidebook, (EMEP / EEA, 2016) https://www.eea.europa.eu/publications/emep-eea-guidebook-2016/part-b-sectoralguidance-chapters/4-agriculture/3-d-crop-production-and/view, last accessed 2016/12/29.

7. Hrdlickova, Z., Michalek, J., Kolar, M., Vesely, V.: Identicication of factors affecting air pollution by dust aerosol PM10 in Brno City, Czech Republic, Atmospheric Environment (42). 8661-8673 (2008).

8. http://www.gios.gov.pl/pl/aktualnosci/315-jak-sie-mierzy-pyl-zawieszony-w-powietrzu, last accessed 2016/12/29.

9. KOBIZE.: Krajowy bilans emisji SO2, NOX, CO, NH3, NMLZO, pyłów, metali ciężkich i TZO za lata 2014 - 2015 w układzie klasyfikacji SNAP. Raport syntetyczny. Warszawa. 515 (2015).

10. KOBIZE.: Wskaźniki emisyjności CO2, SO2, NOX, CO I TSP dla energii elektrycznej (2017).

11. Mazur, M.: Systemy ochrony powietrza. Wyd. AGH, Kraków (2004).

12. Mołocznik, A.: Pyły w środowisku pracy rolnika, Wyd. IMW, Lublin (1995).

13. Muzalewski, A.: Sprawozdanie z Programu Wieloletniego 3.3 (2016).

14. Nadziakiewicz, J.: Źródła zanieczyszczenia powietrza i metody oczyszczania gazów z zanieczyszczeń pyłowych i gazowych. WSEiA, Bytom (2005).

15. Petroeschevsky, A. et al.: Associations between outdoor air pollution and hospital admissions in Brisbane, Australia, Archives in environmental health (56). 37-52 (2001).

16. Poradnik inwentaryzacji emisji zanieczyszczeń do powietrza (EMEP/EEA Air Pollutant Emission Inventory Guidebook 2013) www.eea.europa.eu/publications/emep-eeaguidebook-2013, last accessed 2017/06/29.

17. Regulation of the Minister of the Environment of 13 September 2012 on the assessment of the level of substances in air, Journal of laws of 2012, item 1032.

18. Schenker, M.: Exposures and health effects from inorganic agricultural dusts, Environ Health Perspect 108 (Suppl. 4), PMCID: PMC1637665, pp. 661-664 (2000). https://www.ncbi.nlm.nih.gov/pmc/articles/PMC1637665/, last accessed 2016/12/28.

19. Seedorf, J., Hartung, J.: A proposal for calculating the dustlike particle emissions from livestock buildings, Deutsch Tierarztliche Wochenschrift (108). 307-310 (2001).

20. Sharratt, B., Auvermann, B.: Dust pollution from agriculture Encyclopedia of Agriculture and Food Systems: Edition 2. ISBN 9780080931395. 487 (2014).

21. Takai, H., Pedersen, S., Johnsen, J. O., Metz, J. H. M., Groot Koerkamp, P. W. G., Uenk, G. H., Phillips, V. R., Holden, M. R., Sneath, R. W., Short, J. L., White, R. P., Hartung, J., Seedorf, J., Schröder, M., Linkert, K. H. and Wathes, C. M.: Concentrations and Emissions of Airborne Dust in Livestock Buildings in Northern Europe, Journal of Agricultural Engineering Research (70). 59-77 (1998). 